\title{
Quality Analysis of Hydrosphear Water of Deosar Block in District Singrauli, Madhya Predesh, India
}

\author{
Arvind Dwivedi ${ }^{1}$, H.P.Dwivedi ${ }^{2}$, Sachchidanand Tiwari ${ }^{3}$ \\ Department of chemistry, Govt. Sanjya Gandhi Smrati Auto P.G.College Sidhi M.P., India ${ }^{1-3}$
}

\begin{abstract}
Hydrosphere constitutes all type of water likewise oceans, seas, rivers, streams and glaciers etc. Ground water, a gift of nature, is about $210 X 109 \mathrm{~m} 3(0.66 \%)$ including recharge through infiltration, seepage and evapotranspiration. The findings of this laboratory work to confirm ground water quality by help of water quality parameters and proposed experimental area is District-Singrauli. It is a method of check water quality, is an effective tool to assess spatial and temporal changes in ground water quality. Twelve (12) groundwater samples were collected from open areas during the Monsoon and Post Monsoon season in the year 2014. Experiment was done by considering the 12 groundwater samples collected to comprehensive physico-chemical analysis using standard parameters of experiment. Data obtained from the experiment, the water quality index was carried out by adopting the method. Water quality index rating was carried out to quantify overall ground water quality status of the area. For calculation of index, the following 9 parameters have been considered such as pH, Total Dissolved Solids, Total Hardness, Calcium, Magnesium, Sulphates, Chlorides, Fluorides, and Nitrates. It may be due to more seepage and movement of ground water during post-monsoon
\end{abstract}

Keywords: Hydrosphere Water, Physio-chemical parameter, Deosar Block, Singrauli District, Madhya Predesh.

\section{INTRODUCTION}

Water is essential for the survival of any from life. Today water resources have been the most exploited natural system since man strode the earth. Only 2-3\% of total water on earth is fresh water. Water pollution is classified into four classes likewise - physical, chemical, biological and physiological pollution of water. Physical water pollution brings about changes in water with regard to its color, density, test, turbidity and thermal properties etc. The chemical pollution of water causes changes in acidity, alkalinity/pH, and DO. Biological pollution is caused by bacteria, virus, algae, protozoa etc. Physiological pollution of water is caused by several chemical agents such as chlorine, sulphur dioxide, hydrogen sulphide, ketones, phenols amines etc. According to WHO organization, about $80 \%$ of all the diseases in human beings are caused by water. Once the groundwater is contaminated, its quality cannot be restored by stopping the pollutants from the source. Contamination of groundwater by domestic, industrial effluents and agricultural activity is a serious problem faced by developing countries. The industrial waste water, sewage sludge and solid waste materials are currently being discharged into the environment indiscriminately. These materials enter subsurface aquifers resulting in the pollution of irrigation and drinking water ${ }^{1}$. High rates of mortality and morbidity due to water borne diseases are well known in India. Access to safe drinking water remains an urgent necessity, as $30 \%$ of urban and $90 \%$ of rural households still depend completely on untreated surface or groundwater, while access to drinking water in India has increased over the past decade, the tremendous adverse impact of unsafe water on health continues.

Water quality index is defined as a rating reflecting the composite influence of different water quality parameters. The water quality of this study samples was assessed using the weighted arithmetic index method, taking into account the nine important parameters such as pH, TDS, Total Hardness, Calcium, Magnesium, Sulphates, Chlorides, Fluorides, Nitrates. WQI is calculated from the point of view of the suitability of groundwater for human consumption. Water quality index is one of the most effective tools to communicate information on the quality of any water body ${ }^{3}$. WQI is a mathematical equation used to transform large number of water quality data into a single number. The water supply for human consumption is often directly sourced from ground water without biochemical treatment and the level of pollution has become a cause for major concern. The water used for drinking purpose 
should be free from toxic elements, living and non-living organisms and excessive amount of minerals that may be harmful to health ${ }^{4}$. The present study was investigated various physic-chemical parameters like PH, TDS, Total hardness, calcium, chloride, magnesium, nitrate, fluoride and sulphate etc.

\section{Materials AND Methods}

\subsection{Study Area}

Deosar block located at Singrauli district of Madhya Pradesh, an image of proud history and culture. It forms the northeastern boundary of the state. Singrauli is well known for its coal mines, natural beauty, historical importance and rich cultural roots. Singrauli possesses abundant natural resources with the river Sone draining the district, and with coal deposits which feed major industries across the country. Singrauli district is located on the Northeastern Boundary of the state between 22,475 and 24.4210 North Latitude and 81:1840 and 824830 East longitudes. The district has Singrauli district in the north-east, Koriya district of Chhattisgarh on the east, and Sidhi district on the west.

\subsection{Sample Collection and Processing}

Sampling was done in accordance with grab sampling method polyethylene bottles of one liter capacity to avoided leaching of methods and interaction with the surface wall of the containers bottles were first cleaned with detergent and then socked in $\mathrm{HNO}_{3}$, for 24 hours. Finally the bottles were cleaned and rinsed with distill water during sampling bottles were two to three times with sample to be examined before filling with it .Samples were collected by immersing the rinsed bottles in ground water .All the samples were labeled, showing the source date and time of collection, the samples were refrigerated at $4^{0} \mathrm{C}$ in the laboratory ${ }^{5-7}$ and procedures were followed as per the standard methods ${ }^{8-}$ 9 and different physico-chemical parameters like, PH, TDS, Total hardness, calcium, chloride, magnesium, nitrate, fluoride and sulphate were analyzed.

\section{RESULT AND DISCUSSION}

The ground water samples were analyzed some parameters like, $\mathrm{pH}$, TDS, Total hardness, calcium, chloride, magnesium, nitrate, fluoride and sulphate. Physico-chemical characteristics of the Hydrosphere water sample of study area were analyzed and all the results are shown in table-1and figure-1

\section{1.pH}

The reference value of $\mathrm{pH}$ in drinking water is $6.5-8.5$ according to Bureau of Indian Standard. The all the value of $\mathrm{pH}$ in the study area is found ranged from 7.0-8.2. The seasonal variation shows the $\mathrm{pH}$ values fluctuating minimum during monsoon and maximum in post monsoon at all locations. (Rao et al. 2014) ${ }^{10}$ studied physico chemical and biochemical characterization of ground water near point sources for assessing their quality for user and application and concentration of $\mathrm{pH}$ was reported range from 6.5 to 8.4 .

\subsection{Total Dissolved Solids}

Solids may affect water or effluent quality adversely in a number of ways. Waters with high dissolved solids generally are at inferior waters. The reference range of TDS of the study area is from 131-285 $\mathrm{mg} / \mathrm{l}$ in samples. The seasonal fluctuation shows that to dissolved solids are higher in monsoon due to leaching of surrounding rain water and minimum in post monsoon in most of the locations. (Sharma et al. 2014) ${ }^{11}$ Studied a Physico-chemical Analysis and management of ground water Bodies from 20 locations of Jodhpur Districts, detected the TDS values varied from $960 \mathrm{ppm}$ to $3650 \mathrm{ppm}$.

\subsection{Total Hardness}

The values ranged from 355 to $468 \mathrm{mg} / \mathrm{l}$ of all type of hardness were quiet high with their prescribed standards. The seasonal fluctuation in total hardness of the region shows mini Shrivastav, K.B.L., Mishra, S.P. and Manlick, N. (2014). Ground Water Quality Assessment of Birsinghpur Area, Satna District, Madhya Pradesh, India. Journal of innovative Trends in Science, Pharmacy \& Technology, vol.1 (1), pp 125-132. Minimum was found in monsoon and maximum in post monsoon. The higher value is mainly found owing to abundant availability of limestone rocks in the surrounding area consequently more solubility of $\mathrm{Ca}++$ and $\mathrm{Mg}++$ salts under anaerobic conditions. (Sunita et al. $2005)^{12}$ Studied hydrogeo-chemistry of ground water, gooty Area, Anantapur District, Andhrapradesh and total hardness values were found ranged between 360 to $4040 \mathrm{mg} / \mathrm{l}$. 


\subsection{Calcium}

The maximum concentration of calcium in drinking water in study area ranges between $76-156 \mathrm{mg} / \mathrm{l}$. Calcium is a major constituent of various types of rock. Calcium is a cause for hardness in water and incrustation in boilers. Calcium is an essential constituent of human being. The low content of calcium in drinking water may cause rickets and defective teeth. It is essential for nervous system, cardiac function and coagulation of blood.

\subsection{Chloride}

The Chloride concentration in the study area ranges from $82-114 \mathrm{mg} / \mathrm{l}$. The permissible limit of chloride is $250 \mathrm{mg} / \mathrm{l}$. Chlorides in excess imparts the salty taste to water and people are not accustomed to high chloride are subjected to laxative effect. The chloride values for all the seasons fluctuate from $82-114 \mathrm{mg} / \mathrm{l}$. The seasonal average of chloride values shows maximum in monsoon and minimum in post monsoon in most of the locations. (Gupta et al. 2010) ${ }^{13}$ studied the natural water quality assessment of Gupt Godavari cavern; chitrakoot reported the chlorides concentration ranged between 3.5 to $3.7 \mathrm{mg} / \mathrm{l}$.

\subsection{Magnesium}

The concentration of magnesium in the study area ranges between $38-97 \mathrm{mg} / \mathrm{l}$. chemical softening, reverse osmosis, electro dialysis, or ion exchange reduces the magnesium and associated hardness to acceptable levels. ( Pujar et al. 2014) ${ }^{14}$ studied on determination of BOD, COD, DO and other physicchemical properties of sugsr and cement industries observed magnesium content ranged between 11.6 to $78.08 \mathrm{mg} / \mathrm{l}$.

\subsection{Nitrate}

The concentration of nitrate in the study area ranges from $15-41 \mathrm{mg} / \mathrm{l}$. The reference limit of nitrate is $45 \mathrm{mg} / \mathrm{l}$. Nitrates generally occur in trace quantities in surface waters but may attain high levels in some ground waters. (Srinivas et al. 2012) ${ }^{15}$ Studies on chemistry and Water Quality Index of ground water in Chincholi Taluk, Gulbarga district, Karnataka India, nitrate content was observed ranged from 26.2 to $122.0 \mathrm{mg} / \mathrm{l}$.

\subsection{Fluoride}

The fluoride concentrations were found to be in the range of $0.62-1.17 \mathrm{mg} / \mathrm{l}$. In study area, fluoride concentrations vary with the type of rock that the water flows through but do not usually exceed 10 $\mathrm{mg} / \mathrm{l}$. The maximum seasonal value of fluoride in the area was post monsoon and the minimum in monsoon.

\subsection{Sulphate}

Sulphate may contribute to the corrosion of distribution systems. The sulphate concentrations were found to be in the range of 220 to $418 \mathrm{mg} / \mathrm{l}$. The seasonal average of sulphate values shows maximum in monsoon and minimum in post monsoon in all water sample stations. (Raman et al. 2012) ${ }^{16}$ studied the correlation analysis and Prediction of Characteristics parameters and water quality Index of ground water observed the sulphate values varied from 40.0 to $65.0 \mathrm{mg} / \mathrm{l}$.

Table1. Shows the water quality classification based on WQI value in 2014

\begin{tabular}{|c|c|c|c|c|c|c|c|c|c|}
\hline Months & $\mathrm{pH}$ & $\mathrm{TDS}$ & $\mathrm{TH}$ & $\mathrm{Ca}$ & $\mathrm{Mg}$ & Nitrate & Chloride & Fluoride & Sulphate \\
\hline GW-Jan. & 7.2 & 131 & 450 & 76 & 38 & 15 & 87 & 1.17 & 220 \\
\hline GW-Feb. & 7.1 & 181 & 465 & 80 & 40 & 16 & 82 & 0.95 & 228 \\
\hline GW-Mar. & 7.2 & 270 & 415 & 88 & 55 & 13 & 112 & 0.88 & 239 \\
\hline GW-Apr. & 7.3 & 254 & 417 & 97 & 53 & 18 & 114 & 0.75 & 257 \\
\hline GW-May & 7.2 & 262 & 390 & 108 & 59 & 26 & 110 & 0.69 & 290 \\
\hline GW-Jun. & 7.5 & 285 & 360 & 117 & 82 & 24 & 103 & 0.75 & 350 \\
\hline GW-July & 7.8 & 252 & 358 & 156 & 97 & 36 & 95 & 0.63 & 390 \\
\hline GW-Aug. & 8.2 & 222 & 355 & 152 & 92 & 41 & 99 & 0.62 & 418 \\
\hline GW-Sep. & 8 & 222 & 365 & 148 & 82 & 33 & 98 & 0.68 & 402 \\
\hline GW-Oct. & 7.6 & 210 & 392 & 115 & 71 & 27 & 87 & 0.73 & 409 \\
\hline GW-Nov. & 7.4 & 189 & 395 & 93 & 55 & 22 & 88 & 0.77 & 412 \\
\hline GW-Dec. & 7.2 & 176 & 423 & 85 & 40 & 19 & 82 & 0.81 & 390 \\
\hline
\end{tabular}




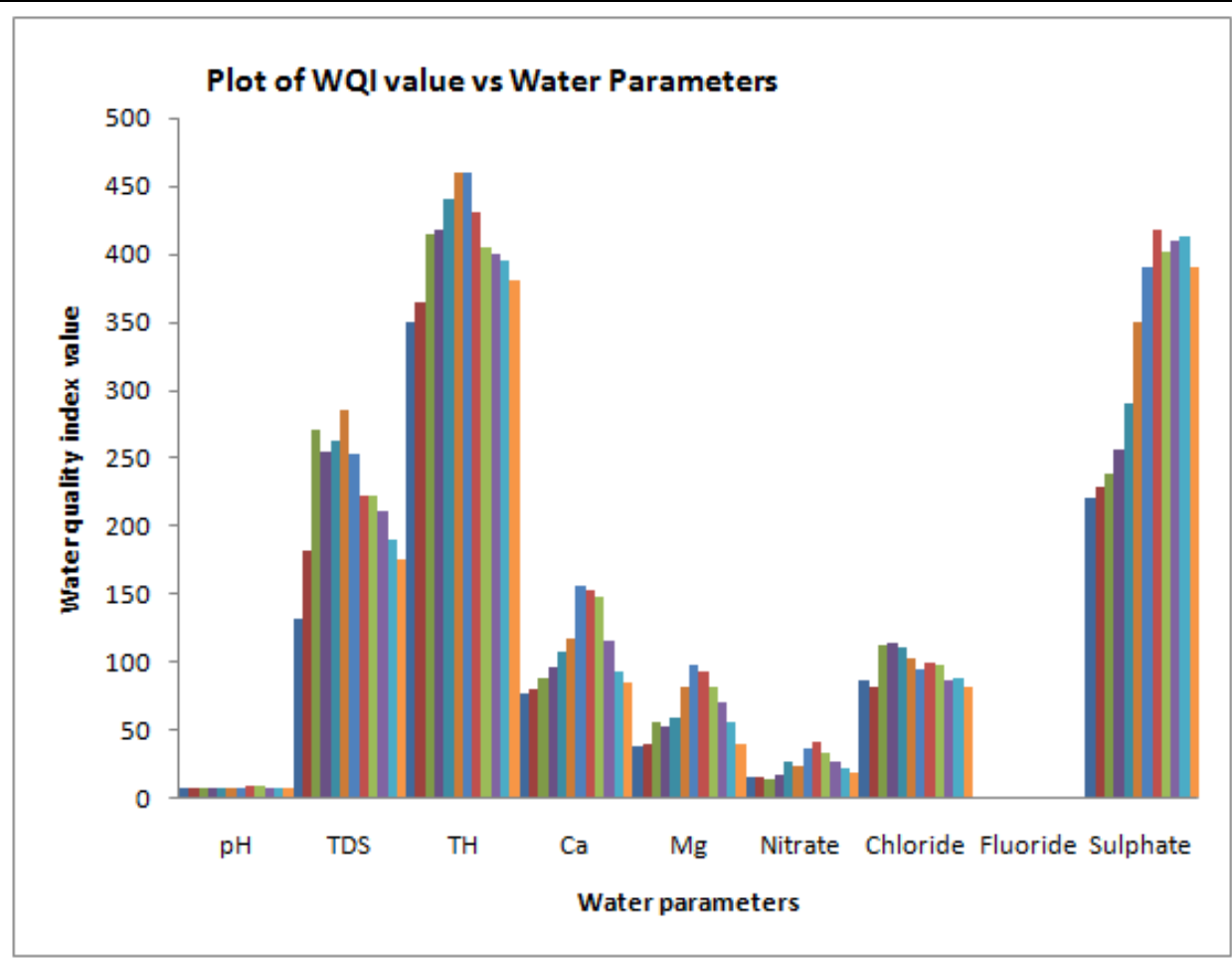

Fig1. Physico-chemical characteristics of the Hydrosphere water of the study Area.

\section{Conclusion}

The ground water samples were taken from the various sites of Deosar block, Singrauli district area were analyzed and the analysis reports that the water quality parameters like $\mathrm{pH}$, total dissolved solids, total hardness, calcium, magnesium, nitrate, chloride, fluoride and sulphate lies within the maximum permissible limit prescribed by WHO and ICMR. The analysis of experimental investigation on quality of groundwater using nine physico-chemical parameters of the study area indicate that in general about the water quality is low for drinking purpose. The Percentage of water quality index 8 shows that maximum in post monsoon and minimum in monsoon period. The overall view of the Water Quality Index of the present study zone had a higher WQI value indicating the deteriorated water quality. A part from ground water assessment, the WQI model can be used for wide ranging of applications. Among other uses, it can help the planner and policy maker when selecting is as for waste disposal and industrial sites.

\section{REFERENCES}

[1] T.R Girija. C Mahanta., and V Chandramouli, Water Quality Assessment of an untreated Effluent Impacted Urban Stream the Bharalu Tributary of the Brahmaputra River, India. Environmental Monitoring and Assessment, 221-236, 2007.

[2] P.N. Palanisamy, .A. Geetha, M .Sujatha, P. Sivakumar and K. Karunakaran.. Assessment of Ground Water Quality in and Around Gobichetti- Palayam Town Erode District, Tamilnadu. EJournal of Chemistry, 4:(3) , 434-439, 2007.

[3] Hooman Adib, Shadi Hassanajili, Mohammad Reza Sheikhi-Kouhsar, Abdolhamid Salahi, and Toraj Mohammadi: Korean Journal of Chemical Engineering , 32, (1), 159-167, 2015.

[4] A.P. Dwivedi, I.P. Tripathi and M. Suresh Kumar, Assessment of soil and Ground water Quality in Rewa District of Vindhyan Plateau (India), Journal Environ. Science \& Engg. 55,(1), 51-64, 2013

[5] M. Z. Hasan, S. P. Pandey, B.N. Pathak, Bulusce. Project No 1428, Neeri Nagpur, 1981.

[6] ICMR, Manual of Standards of Quality for Drinking Water, ICMR Delhi 2nd ed. 1975.

[7] Neeri, Manual on Water and Waste Water Analysis, Nagpur, 1988.

[8] Standard Method for the Examination of Water and Waste Water, APHA AWWA and WEF, $18^{\text {th }}$ ed. 1992.

[9] WHO, Guideline for Drinking Water Quality, Vol 2, Geneva, 1984. 
[10] B. Venkateswara Rao, P. V.S. Machiraju and Ch. V.V. Satyavani, Physico-chemical and Biochemical Characterization of Ground Water Near Point Sources for Assessing their Quality for user End Application, Journal of Applicable Chemistry, 3 :(1), 290-301, 2014.

[11] Sharma, Deepshika, A Physico-chemical Analysis and Management of Ground Water Bodies from Twenty Locations of Jodhpur District, Journal of Applicable Chemistry, 3 :(2), 764- 768, 2014

[12] V. Sunitha, V. Sudarshan, and B Rajeswara Reddy, Hydro geochemistry of Ground Water, Gooty Area, Anantpur District, Andhra Pradesh, India, Poll. Res., 24: (1), 217 - 224, 2005.

[13] L.N. Gupta, S.L.Khare and G.S. Gupta, Natural Water Quality Assessment of Gupt Godavari Cavern, Chitrakoot, IJEP, 30 (6):502-505, 2010.

[14] A.S.Pujar, M.S. Yadawe, U.S. Pujeri, S.C. Hiremath, Vinayak Balappanavar, Shivalingayya, Hiremath, Vishwanath Hiremath, Shivanand mathapati and Danesh Hiremath, RJPBCS 5:(6), 1075-1078, 2014.

[15] K.B.L Shrivastav, S.P. Mishra and N. Manlick, Ground Water Quality Assessment of Birsinghpur Area, Satna District, Madhya Pradesh, India. Journal of Innovative Trends in Science, Pharmacy \& Technology, $1:(1), 125-132,2014$.

[16] S.B.K. Raman, Correlation Analysis and Predication of Characteristics Parameters and water quality Index of Ground water, Poll. Research, 24: (1), 197-200, 2012. 